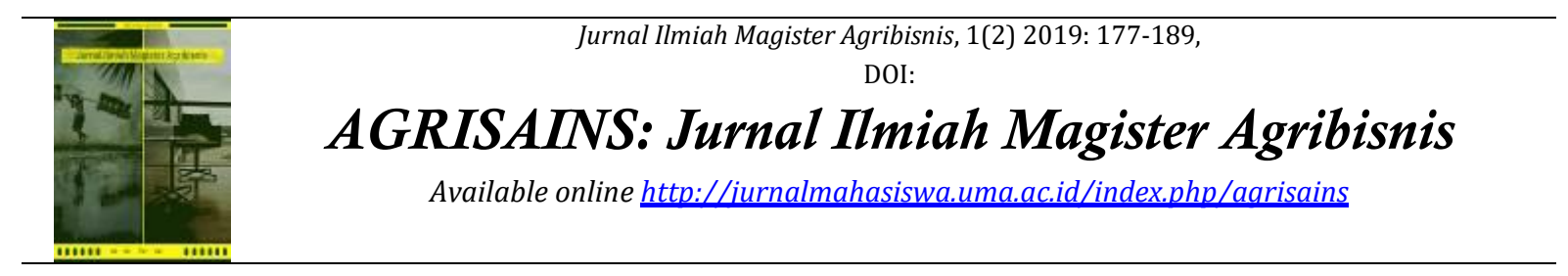

\title{
Strategi Peningkatan Pendapatan Usahatani Padi Sawah di Kota Tebing Tinggi
}

\section{Rice Farming Income Improvement Strategy in Tebing Tinggi City}

\author{
Badan Saragih1), Retna Astuti Kuswardani 2), Syahbuddin Hasibuan ${ }^{3)}$ \\ 1) Program Studi Magister Agribisnis, Pascasarjana, Universitas Medan Area \\ 2,3) Magister Agribisnis, Pascasarjana, Universitas Medan Area
}

\begin{abstract}
Abstrak
Penelitian ini bertujuan untuk mengetahui besarnya pendapatan usahatani padi sawah, mengetahui faktor-faktor yang mempengaruhi pendapatan usahatani padi sawah dan menentukan strategi peingkatan pendapatan usahatani padi sawah di Kota Tebing Tinggi. Penelitian dilaksanakan di Kota Tebing Tinggi Provinsi Sumatera Utara yang di laksanakan dilakukan selama 3 bulan, yaitu April - Juni 2017. Pendekatan penelitian dilakukan secara deskriptif melalui studi kasus. Teknik pengumpulan data dilakukan dengan cara observasi, wawancara, dan pengisian kuesioner. Metode analisis data yang digunakan meliputi analisis analisis $R / C$ rasio, analisis regresi dan analisis Strengths, Weaknesses, Opportunities and Threats (SWOT). Hasil penelitian menunjukkan bahwa usahatani padi sawah di Kota Tebing Tinggi menguntungkan dengan nilai $\mathrm{R} / \mathrm{C}$ rasio 2,54, faktor-faktor produksi berpengaruh nyata terhadap pendapatan usahatani padi sawah di Kota Tebing Tinggi, dan strategi dalam peningkatan pendapatan usahatani padi sawah di Kota Tebing Tinggi yaitu memanfaatkan motivasi petani untuk menggiatkan kelembagaan petani dalam pengelolaan usahataninya, memanfaatkan dukungan pemda dan ketersediaan lahan kosong untuk meningkatkan luas lahan dan akses permodalan, memanfaatkan pengalaman petani dan penggunaan bibit unggul untuk meningkatkan produksi dan memanfaatkan teknologi informasi dan pemasaran yang mudah untuk menjaga nilai ekonomis dan memenuhi kebutuhan konsumen
\end{abstract}

Kata kunci: Strategi, Faktor Internal, Faktor Eksternal, Pendapatan

\section{Abstract}

This study aims to determine the amount of income from lowland rice farming, determine the factors that affect the income of lowland rice farming and determine strategies for increasing the income of lowland rice farming in Tebing Tinggi City. The study was conducted in Tebing Tinggi City, North Sumatra Province which was carried out for 3 months, namely April - June 2017. The research approach was conducted descriptively through case studies. Data collection techniques carried out by observation, interviews, and filling out questionnaires. Data analysis methods used include R / C ratio analysis, regression analysis and Strengths, Weaknesses, Opportunities and Threats (SWOT) analysis. The results showed that lowland rice farming in Tebing Tinggi City was profitable with an $R / C$ ratio of 2.54, the factors of production significantly affected the income of lowland rice farming in Tebing Tinggi City, and strategies in increasing the income of lowland rice farming in Tebing Tinggi City i.e. utilizing farmers' motivation to activate farmers' institutions in managing their farming, utilizing local government support and availability of vacant land to increase land area and access to capital, utilizing farmers' experience and using superior seeds to increase production and utilizing information and marketing technology that is easy to maintain economic value and meet consumer needs

Keywords: Strategy, Internal Factors, External Factors, Revenue

How to Cite: Saragih, B., R.A. Kuswardani, \& S. Hasibuan. (2019). Strategi Peningkatan Pendaptan Usahatani Padi Sawah di Kota Tebing Tinggi. Jurnal Ilmiah Magister Agribisnis, 1(2) 2019: 177-189,

*E-mail: saragihbahdan@yahoo.co.id ISSN 2550-1305 (Online)

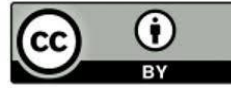


Saragih, B., R.A. Kuswardani, \& S. Hasibuan. Strategi Peningkatan Pendapatan Usahatani Padi Sawah di Kota Tebing Tinggi

\section{PENDAHULUAN}

Sektor pertanian merupakan salah satu sektor yang memiliki peranan penting dalam pertumbuhan perekonomian Indonesia. Sektor pertanian berperan sebagai penyedia pangan bagi konsumsi domestik, penyedia lapangan pekerjaan bagi sebagian besar penduduk, pangsa pasar bagi hasil produksi sektor perekonomian lain dan meningkatkan pendapatan domestik. Sektor pertanian berpengaruh terhadap gizi masyarakat melalui produksi pangan untuk rumah tangga (Soekartawi, 2010).

Subsektor tanaman pangan memiliki peranan yang cukup penting dan strategis dalam pembangunan nasional dan regional. Peranan strategis subsektor tanaman pangan antara lain dalam pengembangan dan penumbuhan ketahanan pangan. Di antara komoditas tanaman pangan yang sangat penting dalam mendukung ketahanan pangan adalah padi. Beras merupakan hasil dari pengolahan padi, salah satu bahan makanan pokok bagi penduduk Indonesia. Oleh sebab itu, beras memegang peranan penting didalam kehidupan ekonomi dan situasi bahan-bahan konsumsi lainnya (Setiawati, 2007).

Padi merupakan komoditas strategis ditinjau dari aspek ekonomi, sosial, dan politik karena tanaman pangan terpenting yang menyangkut hajat hidup dan kebutuhan dasar hampir seluruh rakyat Indonesia serta menjadi prioritas dalam menunjang program pertanian. Di Indonesia usahatani padi masih menjadi tulang punggung perekonomian (Budianto, 2003). Bagi bangsa Indonesia pangan diidentikkan dengan beras. Produktivitas pangan pokok beras tidak dapat dipisahkan dengan usahatani padi sawah. Dalam bidang ekonomi, usahatani padi sawah berhubungan dengan penyerapan tenaga kerja, pertumbuhan ekonomi dan peningkatan pendapatan rumah tangga petani. Beras juga merupakan sumber utama pemenuhan gizi yang meliputi kalori, protein, lemak, dan vitamin (AAK, 2003).

Dalam mengembangkan usahatani, kegiatan utama yang dilakukan adalah peningkatan produksi, meningkatkan produktivitas pertanian dan diperlukan strategi untuk peningkatan pendapatan (Budianto, 2003). Pendapatan menjadi faktor penting dalam menentukan pengeluaran rumah tangga, termasuk pola konsumsi pangan keluarga. Apabila pendapatan meningkat, pola konsumsi akan lebih beragam sehingga konsumsi pangan yang bernilai gizitinggi juga akan meningkat (Ariani, $d k k, 2007$ ). Dalam Pasal 1 PP No.68 tahun 2002 menerangkan bahwa Ketahanan Pangan merupakan kondisi terpenuhinya pangan bagi rumah tangga yang tercermin pada tersedianya pangan yang cukup, baik jumlah maupun mutunya, aman merata, dan terjangkau.

Seiring dengan proses otonomi daerah yang diataur dalam Undang-Undang Nomor 22 Tahun 2000 Tentang Otonomi Daerah yang ditindaklanjuti dengan Peraturan Pemerintah Nomor 25 Tahun 2000, peranan daerah dalam meningkatkan ketahanan pangan di wilayahnya menjadi semakin meningkat. Searah dengan pelaksanaan kebijakan otonomi daerah, pemerintah provinsi dan pemerintah kabupaten/kota dapat berperan aktif dalam upaya meningkatkan ketahanan pangan di wilayah kerjanya (Suwarno, 2010). 
Berdasarkan data tiga tahun terakhir menunjukkan bahwa padi sawah salah satu komoditas pertanian Kota Tebing Tinggi. Dari 5 kecamatan di Kota Tebing Tinggi ada 4 kecamatan yang terdapat lahan sawah, yaitu Kecamatan Padang Hulu, Kecamatan Padang Hulir, Kecamatan Rambutan dan Kecamatan Bajenis. Menurut data BPS, tahun 2013 dengan luas panen 799 ha menghasilkan 4.874 ton GKP, tahun 2014 dengan luas panen 790 ha menghasilkan 4.819 ton GKP dan tahun 2015 dengan luas panen 639 ha menghasilkan 3.898 ton GKP. Hal ini menunjukkan bahwa luas panen tanaman padi sawah semakin menurun setiap tahun diikuti produksi yang menurun juga. Dengan jumlah penduduk di Kota Tebing Tinggi pada tahun 2016 mencapai 156.815 jiwa dengan tingkat pertumbuhan yang terus meningkat setiap tahun. Produksi beras yang dihasilkan belum memenuhi kebutuhan pangan bagi penduduk di Kota Tebing Tinggi. Menurut data Kantor Badan Ketahanan Pangan Kota Tebing Tinggi (2016), kebutuhan konsumsi beras di Kota Tebing Tinggi 18.000 ton per tahun, sedangkan produksi beras hanya 3.000 ton per tahun, maka untuk memenuhi kebutuhan beras pemerintah Kota Tebing Tinggi harus membeli beras dari daerah lain sekitar 16.000 ton per tahun.

Untuk mengetahui strategi yang paling tepat untuk pengembangan usahatani padi sawah maka harus mengetahui faktor-faktor internal maupun eksternal yang menjadi kekuatan, kelemahan, peluang serta ancaman pengembangan usahatani padi sawah tersebut melalui analisis SWOT dapat mengevaluasi kondisi usahatani padi sawah dan menentukan strategi yang tepat. Berdasarkan uraian di atas, perlu dilakukan suatu penelitian tentang "Strategi Peningkatan Pendapatan Usahatani Padi Sawah di Kota Tebing Tinggi".

\section{METODE PENELITIAN}

Tempat penelitian dilaksanakan di Kota Tebing Tinggi Provinsi Sumatera Utara. Pemilihan tempat penelitian dilakukan secara purposive karena Kota Tebing Tinggi merupakan salah satu wilayah perkotaan yang masih memiliki lahan sawah. Pertimbangan lain adalah karena pemerintah Kota Tebing Tinggi melaksanakan program ketahanan pangan. Penelitian dilakukan terhadap usahatani padi sawah yang dilaksanakan kelompok tani yang melakukan usahatani padi sawah. Pengambilan data dilakukan selama tiga bulan, yaitu April - Juni 2017.

Metode penelitian yang digunakan dalam kajian ini adalah metode deskriptif analisis yaitu suatu metode yang meneliti suatu objek pada masa sekarang (Arikunto, 2010). Teknik pengumpulan data dengan cara observasi, wawancara, dan pengisian kuesioner. Metode analisis data yang digunakan meliputi analisis Regresi Linier Berganda dan analisis Strengths, Weaknesses, Opportunities and Threats (SWOT), serta pemilihan strategi dengan menggunakan analisis Quantitative Strategic Planning Matrix (QSPM).

Di Kota Tebing Tinggi terdapat 3 (tiga) kecamatan yang terdapat lahan sawah. Dari 3 (tiga) kecamatan seluruhnya ditetapkan sebagai sampel yang dilakukan secara purposive yaitu Kecamatan Bajenis, Kecamatan Rambutan, dan Kecamatan Padang Hulu dengan pertimbangan bahwa ketiga kecamatan tersebut terdapat petani yang mengusahakan padi sawah. Populasi yang menjadi objek penelitian ini adalah petani 
padi sawah di ketiga kecamatan, yaitu sebanyak 404 orang. Jumlah sampel dalam penelitian ini ditentukan secara purposive sebanyak 30 orang petani yang melakukan usahatani padi sawah. hal ini sesuai pendapat Sugiyono (2007) yang menyatakan bahwa dalam analisis untuk menentukan responden, tidak ada jumlah minimal yang diperlukan, sepanjang responden yang dipilih merupakan ahli di bidangnya.

Pengambilan sampel dilakukan secara teknik sampling proporsional (proportional random sampling) dan acak sederhana (simple random sampling) dengan rumus sebagai berikut (Sugiyono, 2007):

$$
n_{i}=\frac{N_{i} \cdot n}{N}
$$

dimana : $\mathrm{n}_{\mathrm{i}}=$ Jumlah sampel setiap kelompok, $\mathrm{n}=$ Jumlah sampel seluruhnya, $\mathrm{N}_{\mathrm{i}}=$ Jumlah populasi setiap kelompok, $\mathrm{N}=$ Jumlah populasi seluruhnya.

Berdasarkan metode penentuan sampel diatas diperoleh jumlah sampel (responden) dalam penelitian pada kecamatan Bajenis dengan jumlah populasi rumah tangga petani adalah 284 dan jumlah sampel adalah 21, Kecamatan Rambutan dengan jumlah populasi RT petani 24 sehingga jumlah sampel petani 2, dan Kecamatan Padang Hulu dengan jumlah populasi RT petani sebanyak 96 dan jumlah sampel menjadi 7.

Jenis data yang dibutuhkan untuk mendukung penelitian ini adalah data kuantitatif dan data kualitatif. Berdasarkan sumbernya, data yang dikumpulkan dalam penelitian ini adalah data primer dan data sekunder. Metode pengumpulan data merupakan bagian instrumen pengumpulan data yang menentukan berhasil tidaknya suatu penelitian (Arikunto, 2010). Metode pengumpulan data yang digunakan dalam penelitian ini adalah dengan observasi lapangan, wawancara, dokumentasi.

Data yang diperoleh dari lapangan terlebih dahulu ditabulasi dan selanjutnya dianalisis. Untuk hipotesis (1), pendapatan dianalisis dengan rumus matematis (Soekartawi, 2002):

$\mathrm{I}=\mathrm{TR}-\mathrm{TC}$

dimana:

I $\quad=$ Pendapatan usahatani $(\mathrm{Rp})$

$\mathrm{TR}=$ Total penerimaan $(\mathrm{Rp})$

$\mathrm{TC} \quad=$ Total biaya (Rp)

Untuk mengetahui perbandingan antara penerimaan dengan biaya digunakan analisis $\mathrm{R} / \mathrm{C}$ rasio (Suratiyah, 2009) :

dimana:

$$
\begin{aligned}
\mathrm{R} & =\text { Penerimaan }(\mathrm{Rp}) \\
\mathrm{C} & =\text { Biaya }(\mathrm{Rp})
\end{aligned}
$$

Dengan kaidah keputusan:

$\mathrm{R} / \mathrm{C}<1$ maka usahatani padi sawah tersebut tidak menguntungkan/rugi.

$\mathrm{R} / \mathrm{C}=1$ maka usahatani padi sawah tersebut impas.

$1<\mathrm{R} / \mathrm{C}<2$ maka usahatani padi sawah tersebut menguntungkan tapi belum layak dikembangkan. 
R/C $\quad \geq 2$ maka usahatani padi sawah tersebut menguntungkan dan layak dikembangkan.

Untuk hipotesis (2) digunakan analisis regresi linier berganda menggunakan SPSS 20 dengan persamaan sebagai berikut: $Y=a_{0}+b_{1} X_{1}+b_{2} X_{2}+b_{3} X_{3}$ (Suprapto, 2009):

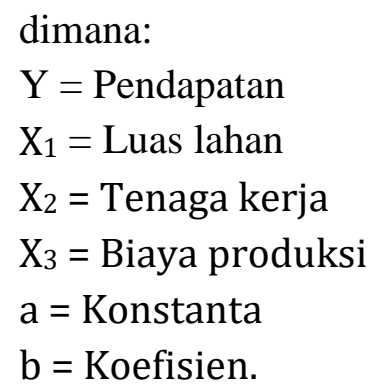

Untuk hipotesis (3) digunakan analisis deskriptif dengan cara menggambarkan dan menjelaskan faktor internal (kekuatan dan kelemahan) dan faktor eksternal (peluang dan ancaman) usahatani padi sawah di daerah penelitian. Proses penyusunan strategis dilakukan dengan melalui tiga tahapan analisis, yaitu tahap masukan data, tahap analisis dan tahap pengambilan keputusan.

\section{HASIL DAN PEMBAHASAN}

\section{Pendapatan Usahatani Padi Sawah}

Pendapatan usahatani padi sawah diperoleh dari selisih biaya yang dikeluarkan dengan penerimaan yang diperoleh dari usahatani tersebut. Biaya produksi usahatani padi sawah di Kota Tebing Tinggi dibagi menjadi 3 yaitu biaya sarana produksi, biaya tenaga kerja dan biaya lain-lain. Berdasarkan hasil penelitian di Kota Tebing Tinggi, rata-rata luas lahan usahatani padi sawah adalah 0,65 ha. Berdasarkan hasil penelitian di Kota Tebing Tinggi, rata-rata biaya total usahatani padi sawah dapat dilihat pada Tabel 1.

Tabel 1. Rata-rata Biaya Total Usahatani Padi Sawah di Kota Tebing Tinggi Tahun 2017

\begin{tabular}{|c|c|c|c|}
\hline \multirow[t]{2}{*}{ No. } & \multirow[t]{2}{*}{ Uraian } & \multicolumn{2}{|c|}{ Biaya } \\
\hline & & $\begin{array}{l}\text { Per Usahatani } \\
\text { (Rp) }\end{array}$ & $\begin{array}{l}\text { Per Hektar } \\
\text { (Rp) }\end{array}$ \\
\hline 1. & Biaya Sarana Produksi & 1.263 .960 & 1.944 .550 \\
\hline 2. & Biaya Tenaga Kerja & 3.228 .000 & 4.966 .150 \\
\hline 3. & Biaya Lain-lain & 2.119 .000 & 3.260 .000 \\
\hline Jum & & 6.610 .960 & 10.170 .700 \\
\hline
\end{tabular}

Sumber : Data Primer (diolah), 2017

Tenaga kerja merupakan salah satu faktor produksi sebagai pelaku kegiatan usahatani. Berdasarkan hasil penelitian di Kota Tebing Tinggi, rata-rata curahan tenaga kerja pada usahatani padi sawah adalah 48,4 HOK per usahatani dan 74,5 HOK per hektar, dengan rata-rata biaya tenaga kerja $\mathrm{Rp} 3.228 .000$ per usahatani dan $\mathrm{Rp}$ 4.966.150 per hektar. Hasil penelitian menunjukkan bahwa penggunaan tenaga kerja dalam keluarga lebih besar dari tenaga kerja luar keluarga, hal ini berarti tenaga kerja dalam keluarga terlibat penuh dalam usahatani padi sawah. Menurut Soekartawi (2010) jumlah tanggungan petani dapat mempengaruhi tenaga kerja, keterlibatan anggota 
keluarga petani mengurangi penggunaan tenaga kerja luar keluarga. Tenaga kerja merupakan salah satu faktor produksi sebagai pelaku kegiatan usahatani padi sawah. Sejalan dengn AAK (2003) bahwa dalam kegiatan usahatani padi sawah memerlukan tenaga kerja lebih besar dari usahatani lainnya. Berdasarkan hasil penelitian di Kota Tebing Tinggi, rata-rata produksi, penerimaan dan pendapatan usahatani padi sawah dapat dilihat pada Tabel 2.

Tabel 2. Rata-rata Produksi, Penerimaan dan Pendapatan Usahatani Padi Sawah di Kota Tebing Tinggi Tahun 2017

\begin{tabular}{lllrr}
\hline No. & Uraian & Satuan & \multicolumn{2}{c}{ Nilai } \\
\cline { 3 - 5 } & & Per Usahatani & Per Hektar \\
\hline 1. & Produksi & $\mathrm{kg}$ & 4.022 & 6.188 \\
2. & Penerimaan & $\mathrm{Rp}$ & 16.769 .220 & 25.798 .800 \\
3. & Biaya Produksi & $\mathrm{Rp}$ & 6.610 .960 & 10.170 .700 \\
4. & Pendapatan & $\mathrm{Rp}$ & 10.158 .260 & 15.628 .100 \\
\hline
\end{tabular}

Sumber : Data Primer (diolah), 2017

Tabel 2 menunjukkan bahwa rata-rata produksi usahatani padi sawah di Kota Tebing Tinggi adalah $4.022 \mathrm{~kg}$ per usahatani dan 6.188 per hektar. Nilai penerimaan sebesar Rp 16.610.960 per usahatani dan Rp 25.798.800 per hektar, dan nilai pendapatan sebesar Rp 10.158.260 per usahatani dan Rp 15.628.100 per hektar. Dilihat dari produksi yang dihasilkan, hasil penelitian menunjukkan tingkat produktivitas usahatani padi sawah 6,18 ton/ha. Menurut BPS Kota Tebing Tinggi, tingkat produktivitas padi sawah di Kota Tebing Tinggi tahun 2015 hanya 6,1 ton/ha, artinya ada peningkatan produktivitas.

Pendapatan merupakan salah satu faktor ekonomi yang paling penting bagi petani. Tingkat pendapatan petani merupakan modal bagi petani dalam berusahatani, menunjukkan kemampuan petani dalam mengelola usahataninya, khususnya dalam menentukan strategi usahatani. Hal ini sesuai dengan pendapat Setiawati (2007) bahwa pendapatan adalah keuntungan atau hasil yang diperoleh petani dari hasil produksinya. Lebih lanjut, Soekartawi (2002) menyatakan bahwa suatu usaha dapat dikatakan memberikan manfaat bila nilai $\mathrm{R} / \mathrm{C}$ ratio diatas $1(>1)$. Semakin besar nilai $\mathrm{R} / \mathrm{C}$ ratio maka semakin layak usaha tersebut dan sebaliknya, dan jika $\mathrm{R} / \mathrm{C} \geq 2$ maka usaha tersebut sudah layak diusahakan. Untuk mengetahui apakah usahatani padi sawah di Kota Tebing Tinggi menguntungkan dan layak dikembangkan, dianalisis dengan $\mathrm{R} / \mathrm{C}$ ratio. Berdasarkan hasil penelitian, rata-rata nilai $\mathrm{R} / \mathrm{C}$ ratio usahatani padi sawah di Kota Tebing Tinggi sebesar 2,54 per usahatani dan 2,53 per hektar. Artinya setiap pengeluaran biaya sebesar Rp 1 memberikan penerimaan Rp 2,54. Nilai R/C 2,54 > 2, menunjukkan bahwa usahatani padi sawah di Kota Tebing Tinggi menguntungkan dan layak dikembangkan.

\section{Pengaruh Faktor-Faktor Produksi Terhadap Pendapatan}

Dalam fungsi produksi terdapat hubungan antara variabel yang dijelaskan (Y) dengan variabel yang menjelaskan (X). Variabel yang dijelaskan berupa output dan 
variabel yang menjelaskan berupa input. Melalui fungsi produksi, hubungan antara faktor-faktor produksi dengan pendapatan dan seberapa besar faktor-faktor tersebut memengaruhi pendapatan dapat diketahui. Berdasarkan hasil penelitian, analisis regresi faktor-faktor produksi yang mempengaruhi pendapatan usahatani padi sawah di Kota Tebing Tinggi dapat dilihat pada Tabel 3.

Tabel 3. Hasil Pengujian Regresi Linier Faktor Produksi Terhadap Pendapatan Usahatani Padi Sawah di Kota Tebing Tinggi Tahun 2017

\begin{tabular}{lllllll}
\hline Variabel & Coefficients & Uji t & \multicolumn{3}{l}{ Uji F } & \\
\cline { 3 - 5 } & & $\mathrm{t}_{\text {hitung }}$ & $\mathrm{t}_{\text {tabel }}$ & $\mathrm{F}_{\text {hitung }}$ & $\mathrm{F}_{\text {tabel }}$ & $\mathrm{R}^{2}$ \\
\hline Konstanta & $-100,816$ & $-0,413$ & 2,056 & 765,185 & 2,96 & 0,988 \\
Luas lahan & 19740,480 & 3,713 & & & & $98,8 \%$ \\
Tenaga kerja & $-5,594$ & $-0,063$ & & & & \\
Biaya & $-0,348$ & $-0,339$ & & & & \\
\hline
\end{tabular}

Sumber : Data Primer (diolah), 2017

$Y=-100,816+1.9740,480 X_{1}-5,594 X_{2}-0,348 X_{3}$

Dari hasil pengujian analisis regresi linier berganda diperoleh koefisien determinasi $\left(R^{2}\right)=0,988$. Nilai koefisien determinasi tersebut dapat diartikan bahwa secara serempak variasi variabel bebas (luas lahan, tenaga kerja dan biaya produksi) dapat menjelaskan seluruh variasi variabel terikat (pendapatan), yaitu sebesar 98,8\% dan sebesar 1,2\% dipengaruhi oleh faktor lain yang tidak diteliti dalam penelitian ini. Sebagaimana dijelaskan oleh Suprapto (2009) bahwa Koefisien determinasi $\left(\mathrm{R}^{2}\right)$ pada intinya mengukur seberapa jauh kemampuan model dalam menerangkan variabel terikat.

Untuk melihat ada tidaknya pengaruh variabel bebas terhadap variabel terikat dapat melihat nilai $\mathrm{F}$ hitung. Dari hasil pengujian dengan uji $\mathrm{F}$ diperoleh nilai $\mathrm{F}_{\text {hitung }}=$ $765,185>$ nilai $F_{\text {tabel }}=2,96$ pada taraf kepercayaan 95\%, maka model regresi linier layak digunakan sebagai fungsi dugaan mengestimasi pengaruh faktor luas lahan, tenaga kerja dan biaya produksi. Faktor-faktor tersebut secara bersama-sama memengaruhi pendapatan.

Rahim dan Hastuti (2007) menyatakan bahwa keberhasilan suatu usahatani tidak terlepas dari faktor-faktor yang mempengaruhinya. Faktor-faktor tersebut adalah luas lahan yang diusahakan, jumlah tenaga kerja yang dialokasikan, biaya produksi yang digunakan, dan kemampuan petani mengalokasikan faktor-faktor produksi yang digunakan. Hasil penelitian diatas sejalan dengan penelitian terdahulu oleh Jonathan (2015) bahwa faktor dari luas lahan, biaya produksi dan harga berpengaruh nyata terhadap pendapatan petani padi sawah di Kecamatan Rawang Kabupaten Asahan.

Koefisien regresi variabel luas lahan ( $\left.\mathrm{X}_{1}\right)$ adalah 19.740,479 dan nilai thitung adalah 3,713 > tabel 2,056 pada taraf kepercayaan $95 \%$, maka faktor luas lahan berpengaruh nyata terhadap pendapatan, dapat diartikan semakin luas lahan yang digunakan petani akan meningkatkan pendapatan. Lahan sebagai salah satu faktor produksi merupakan pabrik hasil-hasil pertanian yaitu tempat dimana produksi berjalan dan sumber hasil 
produksi keluar. Faktor produksi tanah mempunyai kedudukan paling penting. Hal ini terbukti dari besarnya balas jasa yang diterima oleh lahan dibandingkan oleh faktorfaktor lainnya atau dapat dikatakan besar kecilnya produksi dari usahatani antara lain dipengaruhi oleh luas sempitnya lahan yang digunakan petani (Soekartawi, 2010).

Koefisien regresi variabel tenaga kerja $\left(\mathrm{X}_{2}\right)$ adalah $-5,594$ dan nilai thitung adalah $0,063<t_{\text {tabel }} 2,056$ pada taraf kepercayaan $95 \%$, maka faktor tenaga kerja tidak berpengaruh nyata terhadap pendapatan, dapat diartikan bahwa curahan tenaga kerja pada usahatani padi sawah harus ditingkatkan. Dengan demikian dapat dikatakan bahwa variabel tenaga kerja secara statistik tidak signifikan mempengaruhi pendapatan usahatani padi sawah. Kemungkinan yang menjadi penyebabnya, karena kecilnya penggunaaan tenaga kerja, dikarenakan proses kegiatan usahatani padi sawah dilakukan secara serentak sehingga penyediaan tenaga kerjanya kurang maksimal. Menurut Rahim dan Hastuti (2007) kecenderungan yang terjadi sekarang ini, yang melakukan usahatani padi kebanyakan orang tua sedangkan generasi muda lebih tertarik untuk bekerja pada industri atau merantau ke kota-kota besar.

Koefisien regresi variabel biaya produksi $\left(\mathrm{X}_{3}\right)$ adalah $-0,348$ dan nilai thitung adalah $0,339<t_{\text {tabel }}$ 2,056 pada taraf kepercayaan $95 \%$. maka faktor biaya produksi tidak berpengaruh nyata terhadap pendapatan, dapat diartikan bahwa penggunaan biaya produksi harus ditingkatkan. Pada faktor biaya menunjukkan pengaruh yang tidak nyata terhadap pendapatan usahatani padi sawah. Hal ini diduga karena kurang optimalnya penggunaan biaya produksi tersebut. Biaya tersebut dapat ditingkatkan, terutama untuk memenuhi jumlah sarana produksi. Menurut Suratiyah (2009) kurang optimalnya penggunaan biaya produksi karena usahatani padi sawah diduga kurang efisien. Hal ini terbukti dari hasil penelitian menunjukkan bahwa rata-rata jumlah biaya total usahatani padi sawah di Kota Tebing Tinggi sebesar Rp 10.170.700 per hektar. Dari struktur biaya yang dialokasikan pada usahatani padi sawah, biaya tenaga kerja merupakan komponen biaya terbesar yaitu Rp 4.966.150, diikuti biaya lain-lain yaitu Rp 3.260.000. Sedangkan biaya sarana produksi hanya sebesar Rp 1. 944.550.

Faktor-Faktor Internal dan Eksternal Usahatani Padi Sawah

Perkembangan produksi padi sawah mengalami fluktuasi baik itu untuk produksi, produktivitas, dan luas panen. Terkait dengan produktivitas yang berkaitan dengan sistem produksi, secara umum kebijakan program terjadi cenderung untuk meningkatkan pendapatan petani. Analisis lingkungan internal digunakan untuk menilai faktor-faktor kekuatan (Strengths) dan kelemahan (Weaknesses) yang dalam upaya pengembangan usahatani padi sawah di Kota Tebing Tinggi.

Berdasarkan hasil penelitian, faktor-faktor internal yang telah di identifikasi dalam menyusun strategi peningkatan pendapatan usahatani padi sawah di Kota Tebing Tinggi terdapat 5 indikator kekuatan yang diguanakan dalam menyusun strategi peningkatan pendapatan usahatani padi sawah dan terdapat 5 indikator kelemahan yaitu: kekuarangan modal, penggunaan pupuk kurang maksimal, biaya tenaga kerja mahal, luas lahan yang sempit, dan tingkat adopsi teknologi kurang. 
Selanjutnya untuk mengetahui faktor yang paling mendukung dalam peningkatan pendapatan usahatani padi sawah dengan metode matrik strategi internal yang disebut Internal Factor Evaluation (IFE). Berdasarkan hasil penelitian terhadap faktor internal, nilai matrik kekuatan dan kelemahan dalam peningkatan pendapatan usahatani padi sawah di Kota Tebing Tinggi dapat dilihat pada Tabel 4.

Tabel 4. Nilai Matrik Kekuatan dan Kelemahan dalam Peningkatan Pendapatan Usahatani Padi Sawah di Kota Tebing Tinggi Tahun 2017

\begin{tabular}{|c|c|c|c|c|}
\hline \multirow[t]{2}{*}{ No. } & Faktor Internal & Rating & Bobot & Skor \\
\hline & \multicolumn{4}{|l|}{ Kekuatan } \\
\hline 1. & Motivasi petani & 3.7 & 10.63 & 39.34 \\
\hline 2. & Pengalaman petani & 3.8 & 10.92 & 41.49 \\
\hline 3. & Adanya dukungan Pemda & 3.5 & 10.06 & 35.20 \\
\hline 4. & Kesesuaian lahan & 3.3 & 9.48 & 31.29 \\
\hline 5. & Pemasaran yang mudah & 3.1 & 8.91 & 27.61 \\
\hline \multicolumn{2}{|c|}{ Jumlah } & 17.4 & 50.00 & 174.94 \\
\hline & \multicolumn{4}{|l|}{ Kelemahan } \\
\hline 1. & Kekurangan Modal & 2.6 & 10.16 & 26.41 \\
\hline 2. & Penggunaan pupuk kurang maksimal & 2.6 & 10.16 & 26.41 \\
\hline 3. & Biaya tenaga kerja yang mahal & 2.6 & 10.16 & 26.41 \\
\hline 4. & Luas lahan yang sempit & 2.5 & 9.77 & 24.41 \\
\hline 5. & Tingkat adopsi teknologi kurang & 2.5 & 9.77 & 24.41 \\
\hline \multicolumn{2}{|c|}{ Jumlah } & 12.8 & 50.00 & 128.05 \\
\hline \multicolumn{2}{|c|}{ Total Skor Faktor Internal } & 30.2 & 100.00 & 302.99 \\
\hline \multicolumn{4}{|c|}{ Selisih Kekuatan dengan Kelemahan } & 46.90 \\
\hline
\end{tabular}

Sumber : Data Primer (diolah), 2017

Berdasarkan hasil penelitian terhadap faktor internal, nilai matrik kekuatan dan kelemahan dalam peningkatan pendapatan usahatani padi sawah di Kota Tebing Tinggi diketahui bahwa jumlah skor faktor kekuatan 174,94 dan jumlah skor faktor kelemahan hanya 128,05 dan selisih skor kekuatan dengan kelemahan 46,90. Hal ini menunjukkan bahwa faktor kekuatan dalam peningkatan pendapatan usahatani padi sawah lebih besar dari fakor kelemahan yang merupakan hambatan dalam usahatani padi sawah.

Berdasarkan hasil penelitian, faktor-faktor eksternal yang telah di identifikasi dalam menyusun strategi peningkatan pendapatan usahatani padi sawah di Kota Tebing Tinggi terdapat 5 indikator peluang yang digunakan dalam menyusun strategi peningkatan pendapatan usahatani padi sawah di Kota Tebing Tinggi. Selanjutnya untuk mengetahui faktor yang paling mendukung dalam peningkatan usahaani padi sawah dengan metode matrik strategi eksternal yang disebut Eksternal Factor Evaluation (EFE). Berdasarkan hasil penelitian terhadap faktor eksternal, nilai matrik peluang dan ancaman dalam peningkatan pendapatan usahatani padi sawah di Kota Tebing Tinggi dapat dilihat pada Tabel 5.

Dari Tabel 5 diketahui bahwa jumlah skor faktor peluang 172,49 dan jumlah skor faktor ancaman hanya 133,65 dan selisih skor peluang dengan ancaman 38,84. Hal ini menunjukkan bahwa faktor peluang dalam peningkatan pendapatan usahatani padi sawah lebih besar dari faktor ancaman yang merupakan gangguan dalam pengembangan 
Saragih, B., R.A. Kuswardani, \& S. Hasibuan. Strategi Peningkatan Pendapatan Usahatani Padi Sawah di Kota Tebing Tinggi

usahatani padi sawah. Adapun yang dimaksud dengan kelima faktor peluang tersebut adalah adanya kelembagaan petani, ketersediaan bibit unggul, nilai ekonomis, ketersediaan lahan kosong, dan kebutuhan konsumen.

Adapun yang dimaksud dengan kelima faktor ancaman tersebut adalah anomali iklim, harga sarana produksi mahal, kelangkaan tenaga kerja luar keluarga, serangan hama penyakit, dan fluktuasi harga pasar.

Tabel 5. Nilai Matrik Peluang dan Ancaman dalam Peningkatan Pendapatan Usahatani Padi Sawah di Kota Tebing Tinggi Tahun 2017

\begin{tabular}{rlrrr}
\hline No. & Faktor Eksternal & Rating & Bobot & Skor \\
\hline & Peluang & & & \\
\hline 1. & Adanya kelembagaan petani & 3.5 & 10.23 & 35.82 \\
2. & Ketersediaan bibit unggul & 3.2 & 9.36 & 29.94 \\
3. & Nilai ekonomis tinggi & 3.3 & 9.65 & 31.84 \\
4. & Teknologi informasi yang cepat & 3.1 & 9.06 & 28.10 \\
5. & Kebutuhan konsumen & 4.0 & 11.70 & 46.78 \\
\hline$\quad$ Jumlah & 17.1 & 50.00 & 172.49 \\
\hline & Ancaman & & & \\
\hline Anomali iklim & 2.3 & 8.65 & 19.89 \\
2. & Harga sarana produksi mahal & 2.8 & 10.53 & 29.47 \\
3. & Kelangkaan tenaga kerja luar keluarga & 2.7 & 10.15 & 27.41 \\
4. & Serangan hama dan penyakit & 2.7 & 10.15 & 27.41 \\
5. & Fluktuasi harga pasar & 2.8 & 10.53 & 29.47 \\
\hline$\quad$ Jumlah & 13.3 & 50.00 & 133.65 \\
\hline & Total Skor Faktor Eksternal & 30.4 & 100.00 & 306.13 \\
\hline & Selisih Peluang dengan Ancaman & & 38.84 \\
\hline
\end{tabular}

Sumber : Data Primer (diolah), 2017

\section{Strategi Peningkatan Pendapatan Usahatani Padi Sawah}

Hasil penelitian di Kota Tebing Tinggi menunjukkan bahwa nilai matriks faktor strategi internal sebesar 46,90 dan nilai matriks faktor strategi eksternal sebesar 38,84. Setelah melakukan perhitungan bobot dari masing-masing faktor internal maupun eksternal kemudian dianalisis dengan menggunakan matrik posisi. Matrik ini digunakan untuk melihat posisi strategi peningkatan pendapatan usahatani padi sawah di daerah penelitian. Berdasarkan tabel diperoleh nilai $X>0$ yaitu 46,90 dan nilai $Y>0$ yaitu 38,84. Posisi titik kordinatnya dapat dilihat pada kordinat Cartesius berikut ini Gambar 1.

Hasil ini menunjukkan bahwa posisi pengembangan usahatani padi sawah di Kota Tebing Tinggi berada pada kuadran I (Strategi Agresif). Situasi pada kuadran I merupakan posisi yang menguntungkan. Petani mempunyai kekuatan dan peluang sehingga ia dapat memanfaatkan peluang secara maksimal. Seyogyanya menerapkan strategi yang mendukung kebijakan pertumbuhan yang agresif, yaitu: Strategi So: Strategi ini dibuat dengan memanfaatkan seluruh kekuatan untuk merebut dan memanfaatkan peluang sebesar-besarnya. Dengan demikian, strategi sebaiknya yang dijalankan pada kondisi demikian ini adalah strategi kebijakan mendukung 
pertumbuhan agresif (Growth Oriented Strategy) yaitu menggunakan kekuatan untuk memanfaatkan peluang (Hunger dan Wheleen, 2003).

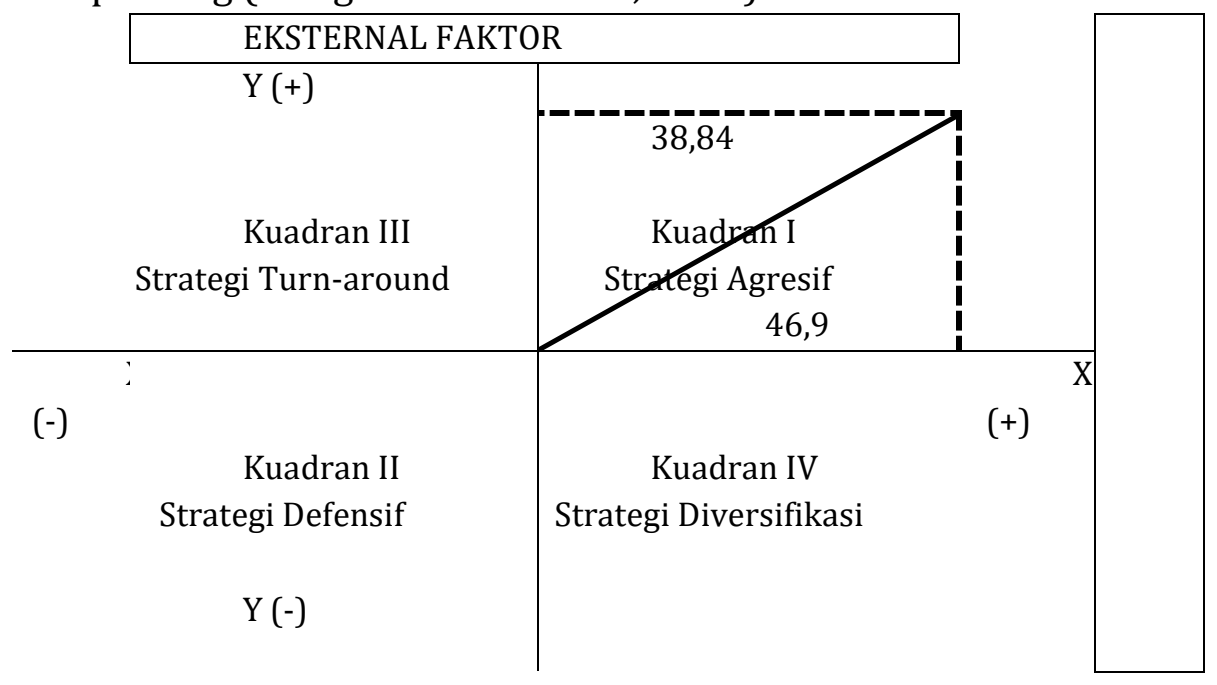

Gambar 1. Matrik Posisi SWOT Strategi Peningkatan Pendapatan Usahatani Padi Sawah di Kota Tebing Tinggi

Berdasarkan hasil penelitian terhadap faktor eksternal, nilai matrik peluang dan ancaman dalam peningkatan pendapatan usahatani padi sawah di Kota Tebing Tinggi diketahui bahwa jumlah skor faktor peluang 172,49 dan jumlah skor faktor ancaman hanya 133,65 dan selisih skor peluang dengan ancaman 38,84. Hal ini menunjukkan bahwa faktor peluang dalam peningkatan pendapatan usahatani padi sawah lebih besar dari fakor ancaman yang merupakan gangguan dalam pengembangan usahatani padi sawah.

Untuk menentukan posisi strategis akibat perubahan lingkungan eksternal dengan memanfaatkan keunggulan lingkungan internal digunakan analisis SWOT. Menurut Rangkuti (2006) proses pengambilan keputusan strategis selalu berkaitan dengan pengembangan misi, tujuan, strategi dan kebijakan organisasi. Dalam penelitian ini, tujuan strategi dalam usahatani padi sawah sawah adalah untuk peningkatan pendapatan.

Untuk mengetahui lebih lanjut strategi pengembangan usahatani padi sawah di Kota Tebing Tinggi adalah mengidentifikasi cara-cara alternatif sehingga organisasi dapat menggunakan kekuatan khususnya untuk menggunakan kesempatan peluang atau untuk menghindari ancaman, dan mengatasi kelemahan. Matriks SWOT mengambarkan bagaimana manajemen dapat mencocokkan peluang dan ancaman eksternal yang dihadapi suatu perusahaan tertentu dengan kekuatan dan kelemahan internalnya. Metode ini mengarah pada brainstorming untuk menciptakan strategi-strategi alternatif yang mungkin tidak terpikirkan oleh manajemen (Hunger dan wheleen, 2003). Hal ini dapat dilihat pada Tabel 6.

Dari Tabel 6 diketahui strategi-strategi apa saja yang dapat dilakukan untuk meningkatkan pendapatan usahatani padi sawah di Kota Tebing Tinggi. Startegi tersebut antara lain strategi SO (menggunakan kekuatan dengan memanfaatkan peluang), strategi 
Saragih, B., R.A. Kuswardani, \& S. Hasibuan. Strategi Peningkatan Pendapatan Usahatani Padi Sawah di Kota Tebing Tinggi

WO (meminimalkan kelemahan dengan memanfaatkan peluang), strategi ST (menggunakan kekuatan dengan mengatasi ancaman), dan strategi WT (meminimalkan kelemahan dengan menghindari ancaman).

Tabel 6. Analisis Strategi Interaksi Peningkatan Pendapatan Usahatani Padi Sawah di Kota Tebing Tinggi Tahun 2017

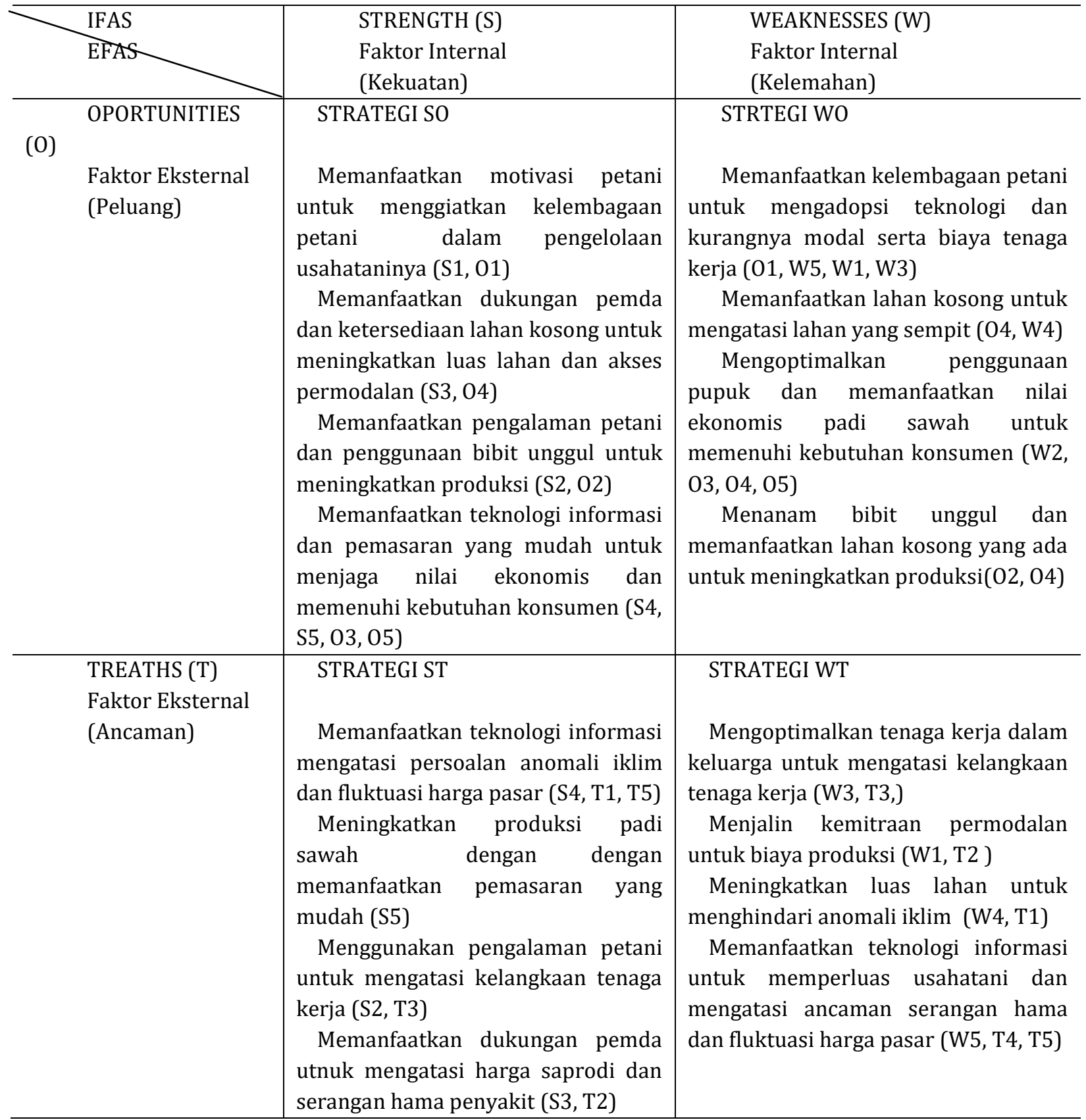

Sumber : Data Primer (diolah), 2017

Dengan mengetahui strategi-strategi untuk meningkatkan pendapatan usahatani padi sawah, manajemen strategi selanjutnya adalah untuk membuat strategi pengembangan 
usaha yang dilakukan oleh para perencana strategi guna menentukan sasaran dalam membuat kesimpulan strategis yang bersifat dinamis dan berkesinambungan.

\section{SIMPULAN}

Berdasarkan hasil penelitian di Kota Tebing Tinggi dapat diambil kesimpulan usahatani padi sawah di Kota Tebing Tinggi menguntungkan. Faktor-faktor produksi dipengaruhi terhadap pendapatan usahatani padi sawah di Kota Tebing Tinggi. Strategi dalam peningkatan pendapatan usahatani padi sawah di Kota Tebing Tinggi yaitu: (1) Memanfaatkan motivasi petani untuk menggiatkan kelembagaan petani dalam pengelolaan usahataninya, (2) Memanfaatkan dukungan pemda dan akses penggunaan ketersediaan lahan kosong untuk meningkatkan luas lahan dan akses permodalan, (3) Memanfaatkan pengalaman petani dan penggunaan bibit unggul untuk meningkatkan produksi, (4) Memanfaatkan teknologi informasi dan pemasaran yang mudah untuk menjaga nilai ekonomis dan memenuhi kebutuhan konsumen. Untuk meningkatkan pendapatan petani usahatani padi sawah di Kota tebing Tinggi disarankan melalui Program Pemberian Modal Usaha, program ini diperlukan untuk memberikan suntikan dana yang berupa pinjaman modal kepada petani, program peningkatan produksi dan produktivitas, dan program Penyuluhan.

\section{DAFTAR PUSTAKA}

AAK. (2003). Budidaya Tanaman Padi. Kanisius, Yogyakarta.

Ariani et. al. (2007). Kinerja dan Prospek Pemberdayaan Rumah Tangga Rawan Pangan Dalam Era Desentralisasi. Kerjasama Penelitian Biro Perencanaan Departemen Pertanian dan UNESCAP-CAPSA, Bogor.

Arikunto, S. (2009). Prosedur Penelitian Suatu Pendekatan Praktek Edisi Revisi V. Penerbit Rineka Cipta, Jakarta.

Badan Ketahanan Pangan Kota Tebing Tinggi. (2016). Konsumsi Beras Kota Tebing Tinggi. Pemko Tebing Tinggi, Tebing Tingi.

Budianto, D. (2003). Kebijaksanaan penelitian dan pengembangan teknologi peningkatan produktivitas padi terpadu di Indonesia. Prosiding Lokakarya pelaksanaan program peningkatan Produktivitas Padi Terpadu (P3T) Tahun 2003. Puslitbangtan, Bogor.

Jonathan, T. (2015). Analisis Faktor-Faktor yang Mempengaruhi Pendapatan Petani Padi Sawah di Kecamatan Rawang Panca Arga Kabupaten Asahan. Fakultas Pertanian USU, Medan.

Rahim, A dan Hastuti. (2007). Ekonomika Pertanian (Pengantar, Teori, dan Kasus). Penebar Swadaya, Jakarta.

Rangkuti, F. (2006). Analisis SWOT Teknik Membedah Kasus Bisnis. Gramedia Pustaka Utama, Jakarta.

Setiawati, A. (2007). Pengembangan Agribisnis Padi Sawah Melalui Pemberdayaan Kelompok Tani. Jurnal Penyuluhan Pertanian Vol 2 No 2 November 2007 STTP Bogor.

Soekartawi. (2002). Prinsip Dasar Ekonomi Pertanian. Raja Grafindo Persada, Jakarta.

Soekartawi. (2010). Analisis Usahatani. UI Press, Jakarta.

Sugiyono. (2007). Statistika Untuk Penelitian. Penerbit Alfabeta, Bandung.

Suprapto, J. (2009). Statistik: Teori dan Aplikasi (Jilid 1 Edisi 7). Erlangga, Jakarta.

Suratiyah, K. (2009). Ilmu Usahatani. Penebar Swadaya, Jakarta.

Suwarno. (2010). Meningkatkan Produksi Padi Menuju Ketahanan Pangan yang Lestari. Jurnal Pangan, Vol 19 No 3 September 2010 Balai Besar Penelitian Tanaman Padi Bogor. 